\title{
GIS, Forest Fire Prevention and Risk Matrix in the National Forest of Khoudida, Sidi Bel Abbes, Algeria
}

\author{
Mayssara El Bouhissi' ${ }^{1}$, Salah Eddine Bachir Bouidjra1, Khéloufi Benabdeli² \\ ${ }^{1}$ Laboratoire Ecodéveloppement des espaces, Université Djillali Liabes de Sidi Bel Abbes, Sidi Bel Abbes, Algeria \\ ${ }^{2}$ Laboratoire Géo-Environnement, Université Stambouli de Mascara, Mascara, Algeria \\ Email: elbouhissimayssara@yahoo.fr
}

How to cite this paper: El Bouhissi, M., Bouidjra, S.E.B. and Benabdeli, K. (2020) GIS, Forest Fire Prevention and Risk Matrix in the National Forest of Khoudida, Sidi Bel Abbes, Algeria. Open Journal of Ecology, 10, 356-369.

https://doi.org/10.4236/oje.2020.106022

Received: April 23, 2020

Accepted: June 8, 2020

Published: June 11, 2020

Copyright $\odot 2020$ by author(s) and Scientific Research Publishing Inc. This work is licensed under the Creative Commons Attribution International License (CC BY 4.0).

http://creativecommons.org/licenses/by/4.0/

\begin{abstract}
Forest fires in Algeria are ravaging an average of more than 32,000 hectares annually despite the prevention and control plan put in place. They are the most damaging factor of degradation of the forest and weigh heavily on the environment and the local economy. Conventional methods for fire prevention and control are time consuming and are not always reliable in view of the complexity and diversity of forest ecosystems. The main idea behind this study is to use the GIS and remote sensing for the development of a fire risk map of the Khoudida State Forest (Algeria). The approach adopted involves three parameters that control the fire behavior, which are: the top-morphology of the field, the combustibility of the plant cover and hazards. For each factor its correlation with risk was evaluated; the combination of the slope, altitude and exposure parameters in the topo-morphological index and the hazard map made it possible to evaluate the average risk for an area of more than 2132 hectares, 1521 hectares high and only 493 hectares, respectively $51.4 \%$, $36.7 \%$ and $11.9 \%$.
\end{abstract}

\section{Keywords}

Fire, GIS, Remote Sensing, Vulnerability, Forest Hazard, Khoudida, Risk

\section{Introduction}

Algerian forest ecosystems are threatened by several natural and anthropogenic factors induced by their floristic composition dominated by conifers, unsuitable silviculture, a long drought period accentuated by climate change, anthropogenic pressures, rural populations who practice animal husbandry and don't have land. Fire is one of the most serious consequences of this situation and requires 
care for lasting protection.

According to the FAO [1], from 1980 to 1990 each year 13.7 million hectares of forest have disappeared. From 1990 to 1995 deforestation affected 56.3 million hectares of forest. The great enemies of the forest are besides fire, diseases, pollution, phenomena mainly recorded in developed areas. Fire is an element that is difficult to control. It is the primary cause of forest degradation on a planetary, local and regional scale.

The recording of burnt areas worldwide in 2003 shows a substantial increase, highlighting if necessary the importance of studying this phenomenon. In the Russian Federation, 23.7 million hectares of forest have been lost, an area almost as large as the United Kingdom. In the United States, some 2.8 million hectares of forest have been destroyed by fire. Canada has registered 2.6 million hectares of burned area. Australia has lost more than 60 million hectares in fires, half of which were caused by humans. Fire is often a human-made phenomenon that plays a large role in changing our environment. This phenomenon is not specific to the Mediterranean basin, but it is particularly important and sensitive in this region [2]. Forest fires are the hot topic par excellence and the year 2019 is considered exceptional in terms of burnt areas. Thus, nationwide, more than 32,000 ha were devastated by the flames, but above all, there were losses of human life. [3].

Statistics for the period 1983-2018 give a total area burned down in the order of 920,000 ha for a total number of 33,000 households, an average per household of nearly 27.87 ha. This figure is quite questionable compared to the total forest area which is only 4 million hectares. This situation makes the forest formations of Algeria one of the most threatened areas which must imperatively benefit from protection measures in order to assure them the sustainability of their roles both in biological diversity and in socio-economic aspects [4].

The technique chosen to fight against this scourge comes down to the implementation of means of control without taking into account the preventive aspect which remains decisive to overcome this recurring phenomenon. Only a strategy based on risk management through flexible mapping would make it possible to sustainably manage the protection of these ecosystems.

It has become necessary to better understand the phenomenon of forest fires, its dangers, its challenges in order to target the risks.

Many organizations have long had the tools to monitor the managed space and help them make decisions. Many thematic maps have therefore been developed and meet specific needs (geological maps, risk maps, tourist maps, etc.). The development of GIS, the digital image obtained by satellite remote sensing, has proven to be very useful for monitoring evolutionary phenomena such as desertification, erosion, floods and forest fires [5].

The complexity and diversity of data relating to the forest environment and fires have favored the development of systems capable of meeting the needs for collecting, analyzing and representing environmental phenomena and necessary models or indices describing compliance with the fire hazard. 
Currently, there is a strong demand for forest fire risk mapping. Several works have been interested in this phenomenon in the region for the Ghetarnia forest, the Nesmoth forest and the Kounteida forest [6] [7], the Khoudida forest fairly representative of all the forest formations in the eastern region indicated.

The methodological approach is based on the application of the model which is essentially based on the following indicators: vegetation, topography, land use and anthropogenic factors [8]. The floristic composition and the structure of the forest formations of the north of Algeria made the northern part of the country particularly exposed to the risks of forest fires. Characterized by a long period of drought of more than 7 months, the semi-arid climate accentuates this predisposition to fires. In addition, the strong presence of easily flammable species and the permanent presence of residents and their herds are also factors involved in the start of fires [9].

\section{Materials and Methods}

\section{Characterization of the study area}

The state forest of Khoudida (Figure 1) is located (-0.493100 and 34.805995 "WGS 84"), its proximity to the agglomerations of Telagh only $2 \mathrm{~km}$ southeast and Téghalimet $6 \mathrm{~km}$ south: the forest is classified in a triangle formed by the highways connecting Telagh, Teghalimet and Merine and is an area at high risk of fire. The bioclimate of the region is semi-arid with a cool variant with average

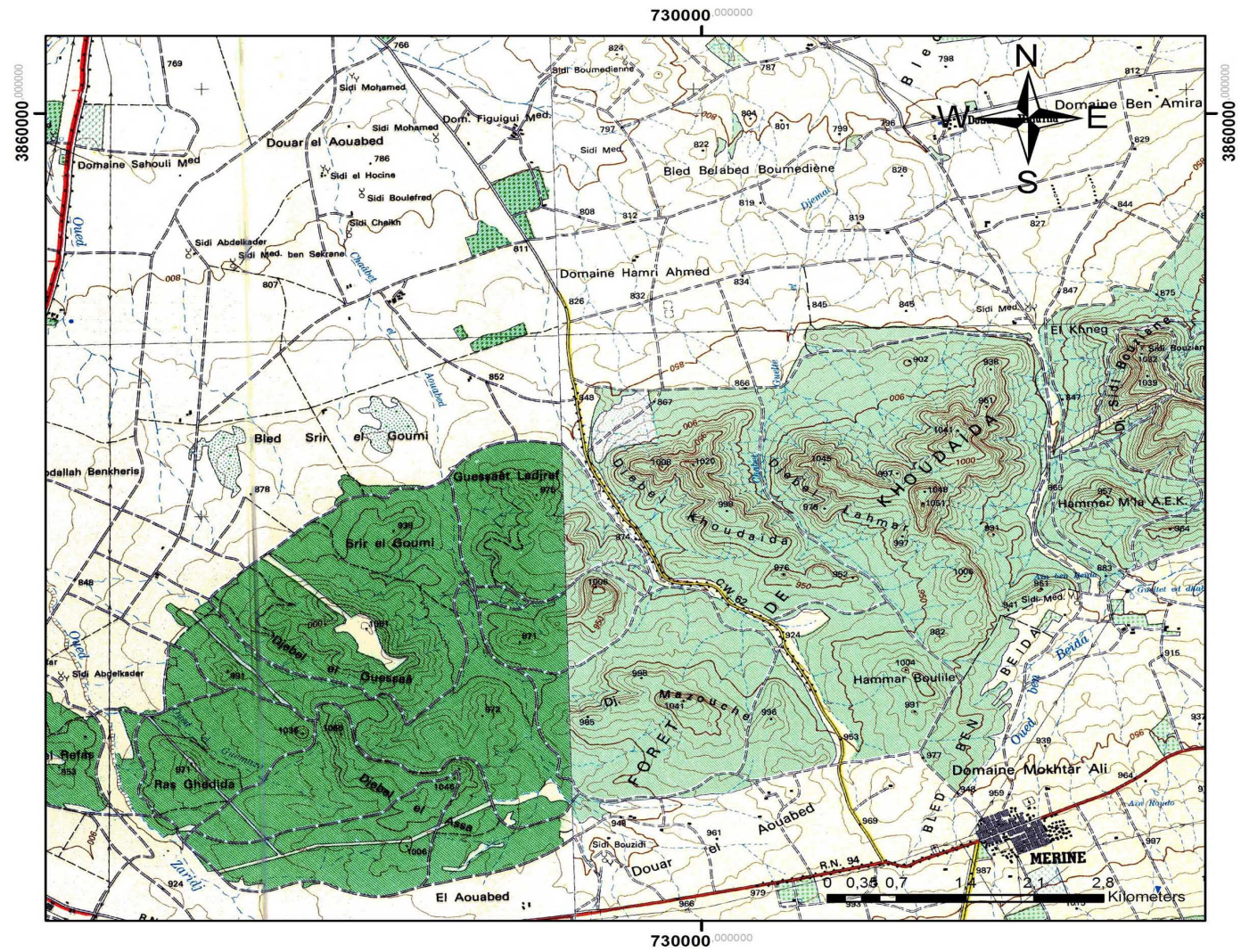

Figure 1. Khoudida forest location map. 
precipitation of around $320 \mathrm{~mm}$ and average temperatures of the coldest month of $6^{\circ} \mathrm{C}$. The soil remains dominated by rendzines and brown limestone soils with low organic matter content and an A0 Horizon composed mainly of Aleppo pine needles and dry wood twigs. It occupies an area of $4226 \mathrm{Ha}$ dominated by groups of Pinetum halepensis, Tetraclinetum articulata, Quecetum illicis and the presence of Juniperus oxycedrus.

The representative procession of this forest is composed of species according to their recovery rate as follows: Pistacia lentiscus, Phillyrea angustifolia, Quercus coccifera, Cistus villosus, Calicotome spinosa and Stipa tenacissima [10].

\section{Materials and methods}

The methodological approach adopted includes several indices, namely: the vegetation indicator, the topo-morphological indicator and the anthropogenic indicator which are respectively linked to the type of vegetation, the slope, the exposure and the distance grouped or diffuse housing. These will be used to calculate the risk indices of the state forest of Khoudida (Figure 2) and the determination of high-risk areas, and forest management will be proposed on the basis of these indices. GIS software was used for data processing with ARCGIS software.

The cartographic documents used are the Senatus Consult card for the delimitation of the national forest of Khoudida (Figure 2); the Digital Terrain Model (DTM) obtained from the ASTER GDEM image (radar satellite image) with a resolution of 30 meters (March 2018) with a geographic projection, Datum WGS 84; the satellite images correspond to the region using Google Earth and the national forest inventory (NFI) drawn up by the National Bureau for Rural Development Studies in 2008 [11].

The methodological approach for calculating the forest fire risk index is based on the DEM combining the slope, exposure and altitude with $\mathrm{IM}=3 \mathrm{P}+(\mathrm{ExM})$

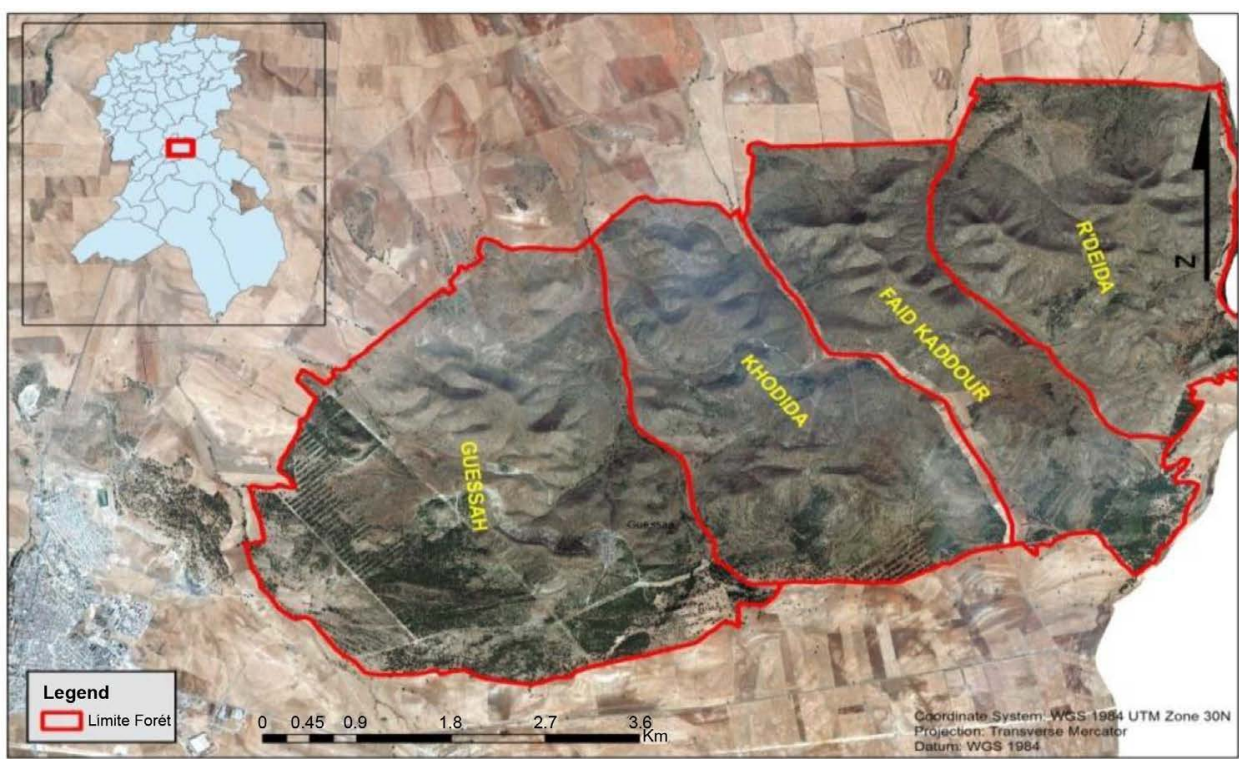

Figure 2. Delimitation of the cantons of the national forest of Khoudida. 
which gives the Topo-morphological Index; the biomass coefficient of BM vegetation induced from the land cover map and the combustion index according to the formula of Xu, Didon and Erten [12] [13] [14].

$\mathrm{IC}=39+0.23 \mathrm{BV}(\mathrm{E} 1+\mathrm{E} 2-7.18)$ makes it possible to calculate the hazard (the Hazard = IC $\times \mathrm{BM} \times \mathrm{IM}$ ); the data collected from the field in terms of urbanization and anthropic pressures. The procedure for calculating forest fire risk indices is based on the following two components: the first consists of the georeferencing of all the images and maps used, namely the large state map, the land survey diagrams national forest territory and the second concerns the production of the different layers of information in vector mode of the types of formation, as well as the types of species and the biovolume of the fuel of each stratum. The combustibility of the vegetation was estimated from indices relating to its composition (forest assessment maps produced by the forest service of Sidi Bel Abbès).

The index assessment (CI) was carried out using the combustibility index method. The latter is based on the biovolume of the BV plant formation obtained by adding the recovery rates of the 4 vegetation strata (high woodland, low woodland, herbaceous, litter) to which is added the recovery rate of snags and dead wood. Each of these recovery rates is between 0 (absence of stratum) and 10 (stratum forming a closed cover); the biovolume is therefore between 0 and 50 .

The caloric intensity of E1 and E2 is between 1 and 8 for the two dominant species: E1 for tall woody and E2 for low or herbaceous woody [15] [16].

The evaluation of the biovolume and the caloric intensity notes necessary for establishing the combustibility index were the subject of systematic field studies. It should be noted that this calorific potential is only a "biological" risk independent of any negative human action (inflammation). The combustibility of a plant formation appears in the study region to depend above all on the nature of the species that compose it (Table 1).

\section{Results and Discussions}

The combination of the different layers of information represented by the maps of slopes, exposures, altitudes and topo-morphological below.

The combination of the different maps makes it possible to create the map of exposure to fire risks according to three levels: low, medium and high through the combined map between altitude, exposure and slope.

The analysis of the risks at the level of the impact of the slope makes it possible to appreciate that on the map of the slopes $73 \%$ of the surface presents a low risk, which is an area of 3021 ha, the average risk occupies $24 \%$, that is to say $1009 \mathrm{Ha}$. The high to low risk occupies $3 \%$ or 116 hectares (Figure 3).

The altitude map revealed that the study area is between $762 \mathrm{~m}$ and $1294 \mathrm{~m}$ with the lower slopes occupying $46.9 \%$ of the forest area, followed by the average slopes with more than $29 \%$, the bottoms and plateaus valleys as well as total ridges $23 \%$ (Figure 4 ). 
Table 1. Summary tables of the different zones.

\begin{tabular}{|c|c|c|c|c|c|c|c|c|c|c|c|c|}
\hline & Zones & 1 & 2 & 3 & 4 & 5 & 6 & 7 & 8 & 9 & 10 & 11 \\
\hline & Altitudes & 962 & 976 & 1049 & 1017 & 1107 & 985 & 1027 & 972 & 983 & 983 & 985 \\
\hline & \multirow{2}{*}{ Coordonnées } & $\mathrm{X} \quad 34.78$ & 34.78 & 34.79 & 34.78 & 34.78 & 34.78 & 34.79 & 34.80 & 34.80 & 34.80 & 34.79 \\
\hline & & $\mathrm{Y}-0.46$ & -0.53 & -0.52 & -0.51 & -0.51 & -0.49 & -0.48 & -0.84 & -0.46 & -0.46 & -0.47 \\
\hline & \multicolumn{12}{|c|}{ BV } \\
\hline & $\begin{array}{c}\text { Herbaceous } \\
\text { vegetation }\end{array}$ & 20 & 10 & 10 & 10 & 20 & 7 & 5 & 10 & 5 & 5 & 8 \\
\hline & $\begin{array}{c}\text { Arboreal } \\
\text { vegetation }\end{array}$ & 20 & 15 & 10 & 10 & 30 & 5 & 15 & 30 & 20 & 40 & 40 \\
\hline & $\begin{array}{c}\text { Shrub } \\
\text { vegetation }\end{array}$ & 2 & 0 & 25 & 10 & 40 & 0 & 0 & 0 & 15 & 0 & 0 \\
\hline \multirow{5}{*}{ IC } & $\begin{array}{c}\text { Tree } \\
\text { vegetation }\end{array}$ & 5 & 25 & 5 & 10 & 30 & 38 & 20 & 0 & 10 & 0 & 0 \\
\hline & \multicolumn{12}{|c|}{ E1 } \\
\hline & & $\begin{array}{l}\text { Aleppo } \\
\text { pine }\end{array}$ & $\begin{array}{l}\text { Aleppo } \\
\text { pine }\end{array}$ & $\begin{array}{c}\text { Barbary } \\
\text { thuja }\end{array}$ & $\begin{array}{l}\text { Aleppo pine }+ \\
\text { Barbary thuja }\end{array}$ & $\begin{array}{c}\text { Barbary } \\
\text { thuja }+ \\
\text { Aleppo pine }\end{array}$ & $\begin{array}{l}\text { Holm oak } \\
+ \text { Aleppo } \\
\text { pine }\end{array}$ & $\begin{array}{l}\text { Aleppo } \\
\text { pine }\end{array}$ & & $\begin{array}{l}\text { Aleppo } \\
\text { pine + } \\
\text { Cypress }\end{array}$ & & \\
\hline & \multicolumn{12}{|c|}{ E2 } \\
\hline & & $\begin{array}{c}\text { Esparto } \\
\text { grass + } \\
\text { herbue }\end{array}$ & $\begin{array}{l}\text { Esparto } \\
\text { grass + } \\
\text { herbue }\end{array}$ & Maquis & $\begin{array}{c}\text { Esparto grass } \\
\text { and lentisk }\end{array}$ & $\begin{array}{c}\text { Rosemary } \\
\text { and lentisk }\end{array}$ & $\begin{array}{c}\text { Esparto } \\
\text { grass }\end{array}$ & Rosemary & Lentisk & $\begin{array}{c}\text { lentisk and } \\
\text { esparto } \\
\text { grass }\end{array}$ & $\begin{array}{c}\text { White } \\
\text { wormwood }\end{array}$ & Maquis \\
\hline BM & Biomes & Steppe & Forest & Maquis & Forest & Forest & Forest & Forest & Maquis & Maquis & Maquis & Maquis \\
\hline
\end{tabular}

BV: the biovolume of the plant formation-E1: caloric intensity notes for tall woody species-E1: caloric intensity notes for low and herbaceous woody species.

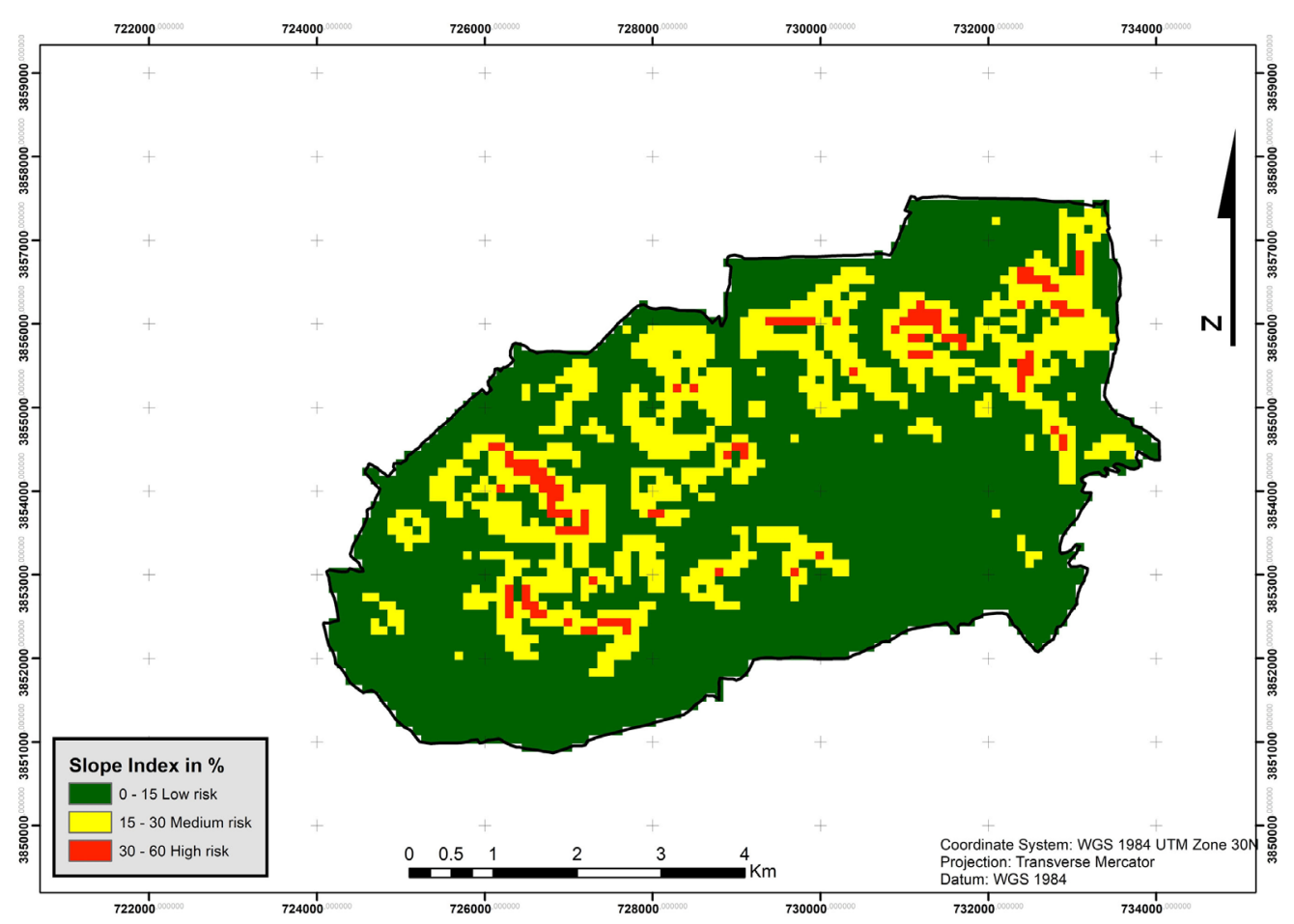

Figure 3. Slope map. 


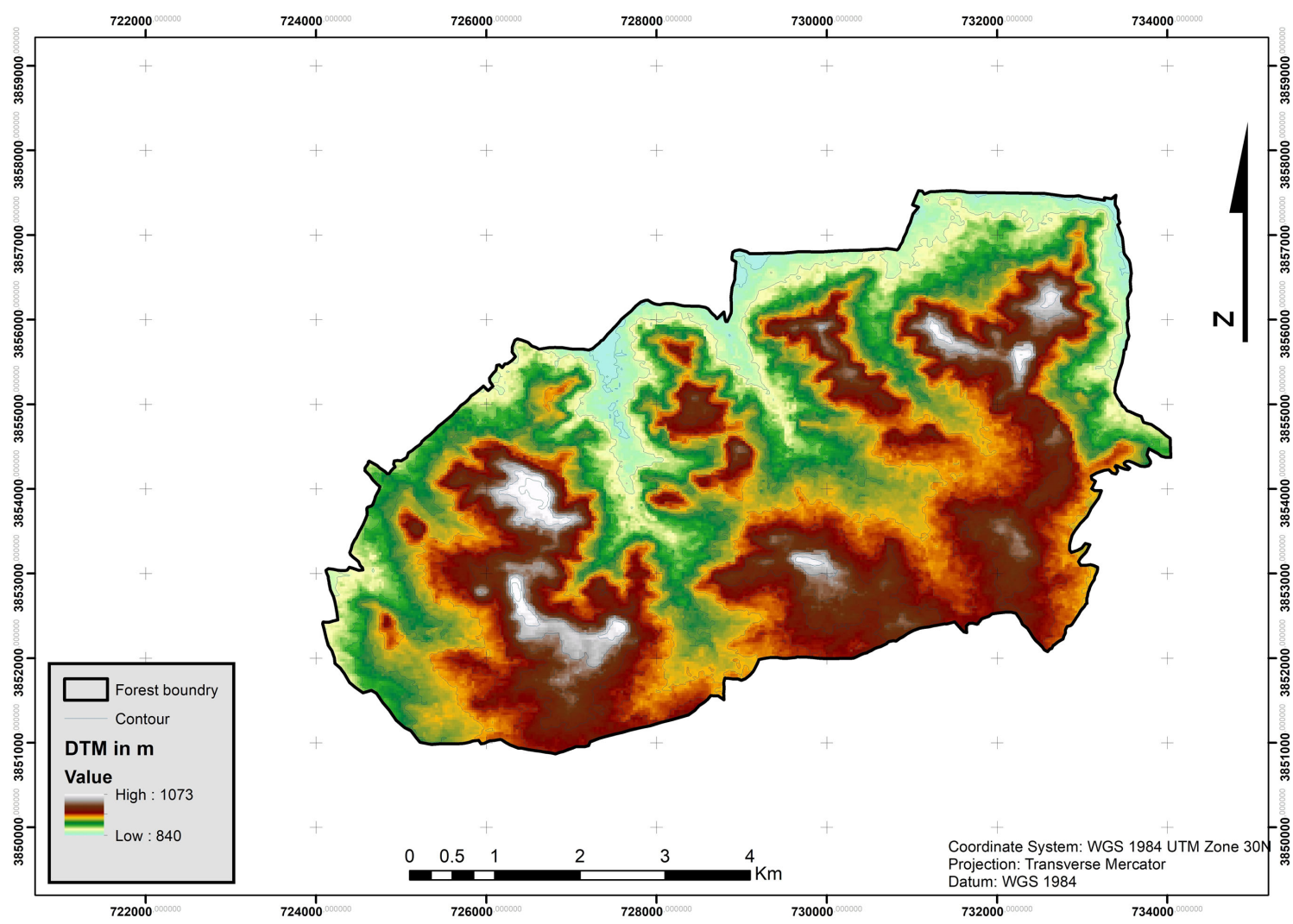

Figure 4. Altitudes map.

The exposure map (Figure 5) shows that $29 \%$ of the area is at high risk, or 1889 ha. The medium risk class occupies $25 \%$ or 1219 hectares and the last low risk class occupies only $46 \%$ with an area of 1038 hectares.

The topo-morphological index (Figure 6) which combines all the parameters assesses the average risk for an area of more than 2132 hectares, strong on 1521 hectares and low on only 493 hectares. The combination of the factors described above led to the production of another derived map, "the map of potential fire risks".

\section{Validation}

By observing the locations of burnt areas in the Khoudida forest, it is possible to establish a correlation between stationary factors (slope, exposure, altitude) and the possibility of fire. We deduce that these parameters have an influence on the risk of fire. A high altitude, steep, north facing area is generally less congested and therefore less prone to fire. These elementary hypotheses remain to be verified by a more in-depth study, but can be used to produce the combustibility map (Figure 7) which is more relevant. It is based on the land use map in which all types of formations and groups of plants are represented. To estimate combustibility, the model developed by Mariel (1995) was adopted where the combustibility index is in the form: $\mathrm{CI}=39+0.23 \mathrm{BV}(\mathrm{E} 1+\mathrm{E} 2-7.18)$. With BV: the biovolume of vegetation; E1: combustibility notes for tall woody plants and E2: 


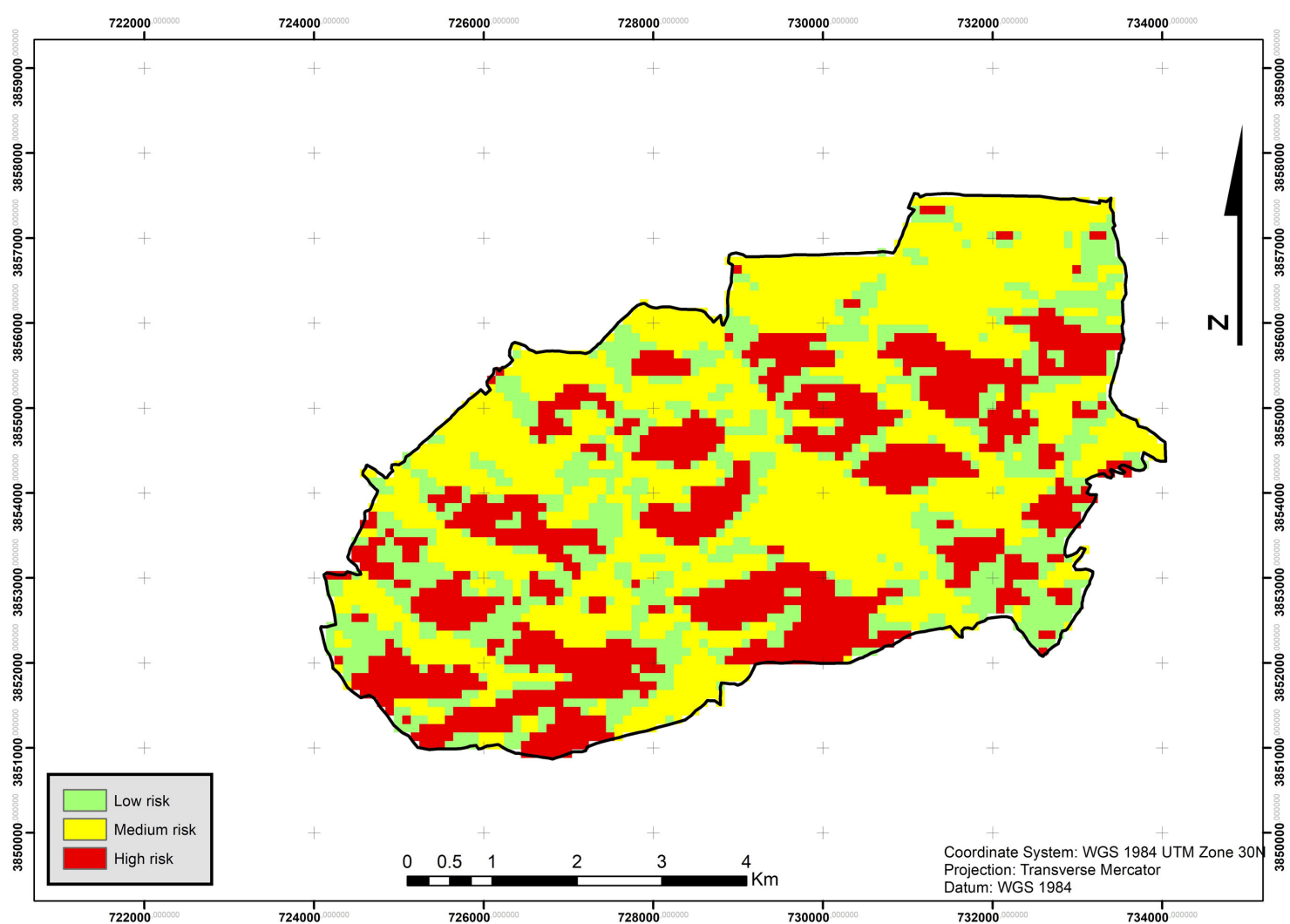

Figure 5. Exposure map.

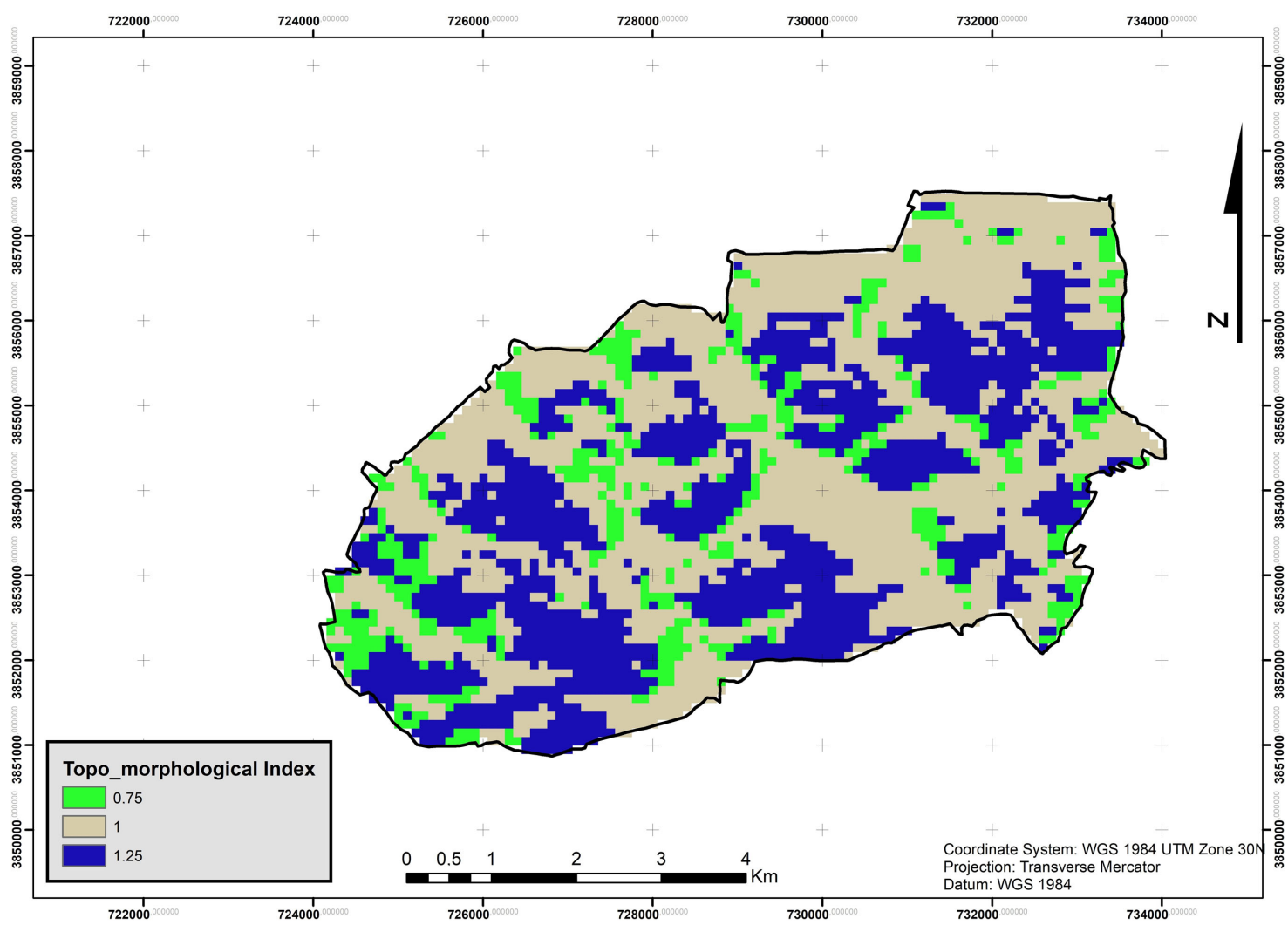

Figure 6. Topo-morphological map. 


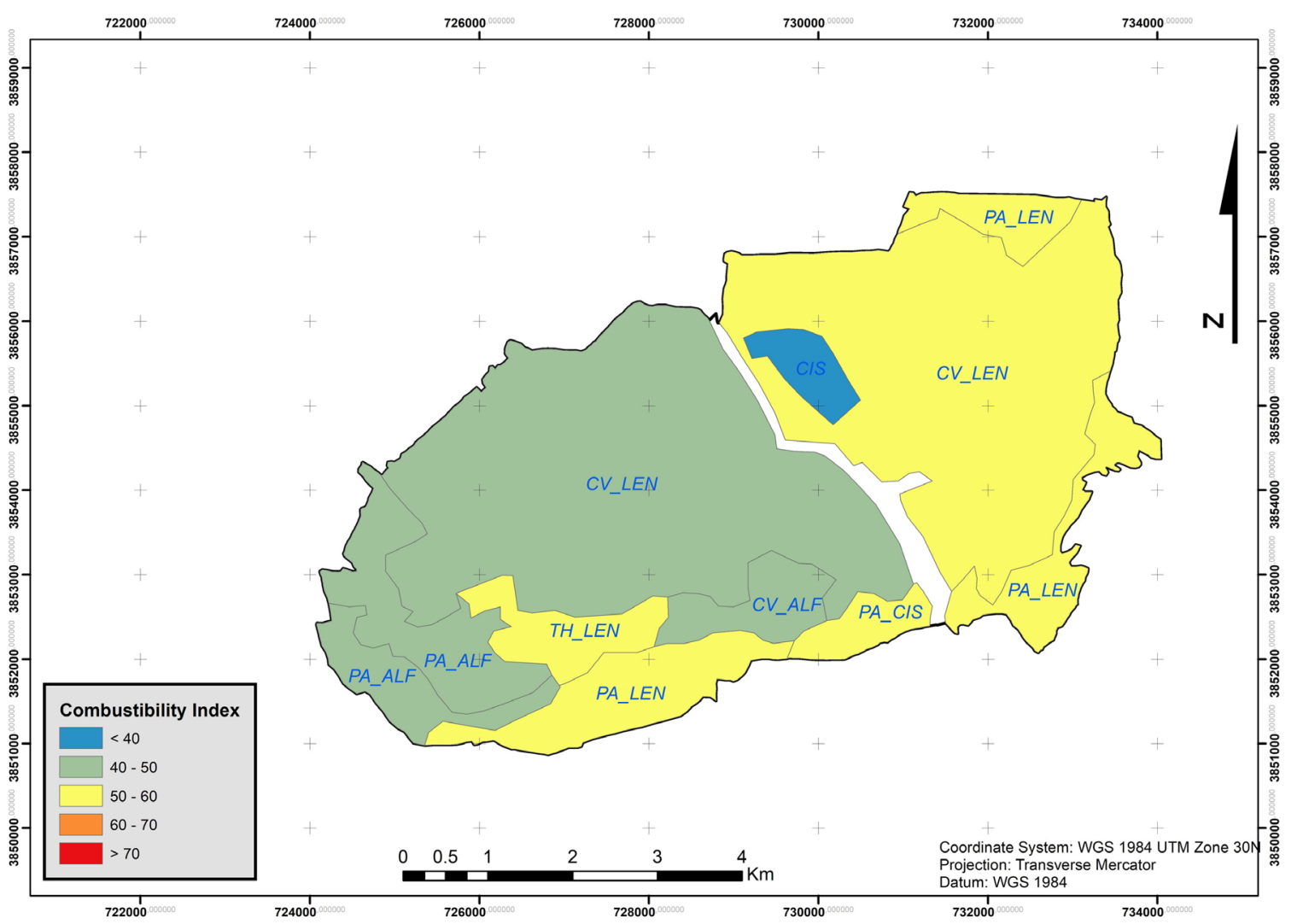

Figure 7. Distribution of plant formations according to their combustibility indices.

combustibility notes for low woody plants or herbaceous plants [14] [15]. Thus, a combustibility index has been assigned to each group of plants in order to assess the risk that the latter may involve; this index varies between 1 and 8 . The value 1 is assigned for a plant species with low combustibility such as sagebrush is 8 for a highly combustible plant species such as Aleppo pine. The main plant formations making up the Khoudida forest are: the forest, the raised scrub, the low scrub, the garrigue and the spaces occupied by a periodic herbaceous layer. All these formations are characterized by forest species playing a decisive role in the risk of fire such as Aleppo pine, lentisk, alfa and rockrose.

The statistical treatment shows several combustibility at the level of the forest of Khoudida, which is between 50 to 60 concerns an area of 1980 hectares, between 40 and 50 an area of 1990 hectares and that of less than 40 is located at ground level occupies only 76 hectares (Figure 8 and Figure 9).

The risk map (Figure 10) is the result of the interaction of three types of indices: the topo-morphological index IM, the biomass index BM and the combustibility index IC. The representation of zones by hazard class can be summarized as in Table 2.

According to Figure 10, the superposition of three factors, topo-morphology, combustion of plant species and biomass, made it possible to obtain a thematic map of the risk of fire in the forest of Khoudida. Each factor is characterized by a variable weighting index according to its impact on the fire risk. 


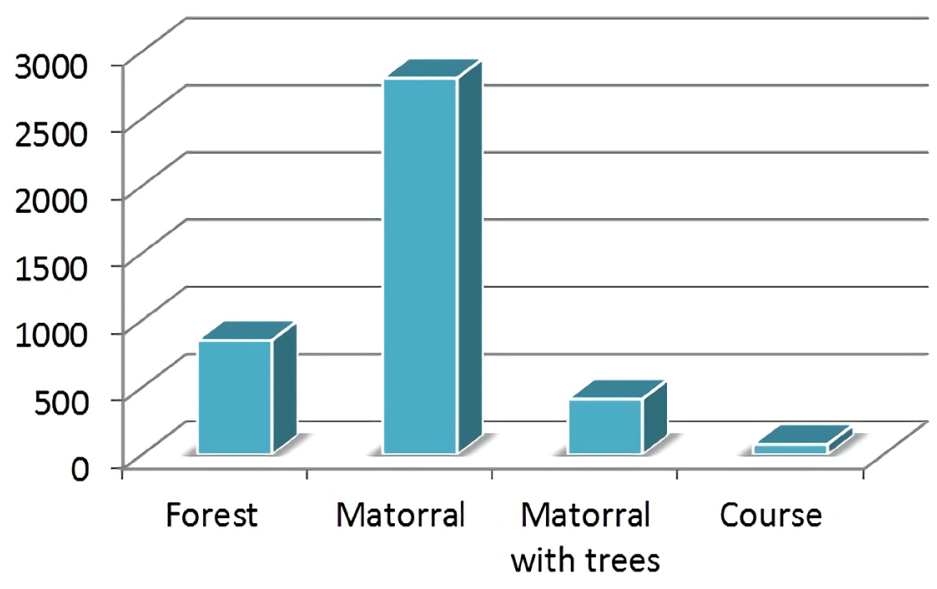

Area in Hectares

Figure 8. Distribution of area by risk of combustibility.

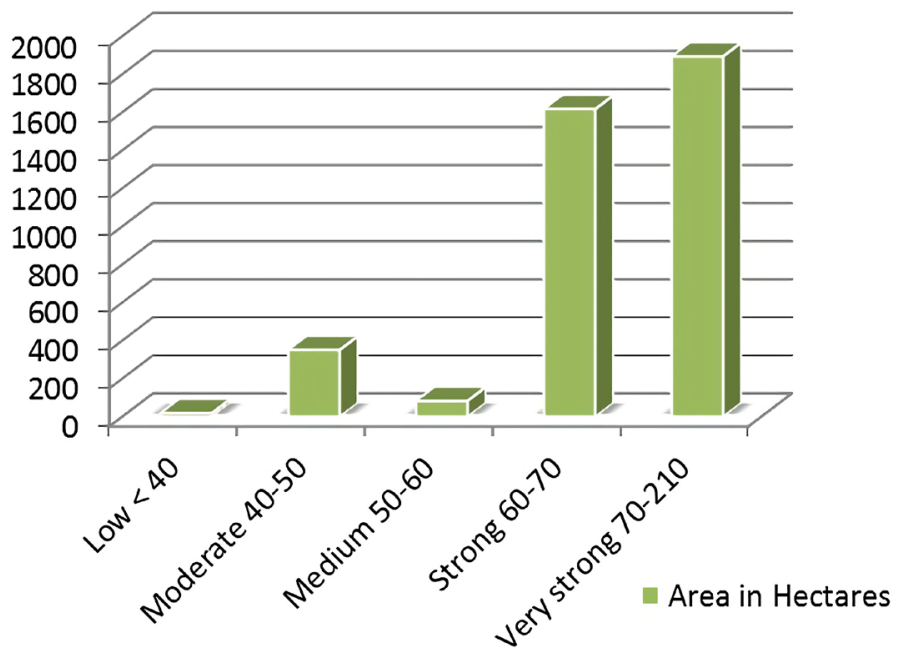

Figure 9. Area by hazard classes.

Table 2. Hazard class and area concerned.

\begin{tabular}{ccc}
\hline Hazard index & Rate & Area in hectares \\
\hline Very strong & 47.33 & 1893 \\
Strong & 40.40 & 1616 \\
Moderate & 8.75 & 350 \\
Medium to low & 2.50 & 100 \\
\hline
\end{tabular}

The combination of the topo-morphological map and risk factors with the risk map indicates that the fire risk is located only at the level of the forest formations and cannot threaten the dwellings, especially since they are all located at more $300 \mathrm{~m}$ from risk areas. The assessment of the reliability of the fire risk mapping is based on a validation approach in the field through four stations. 


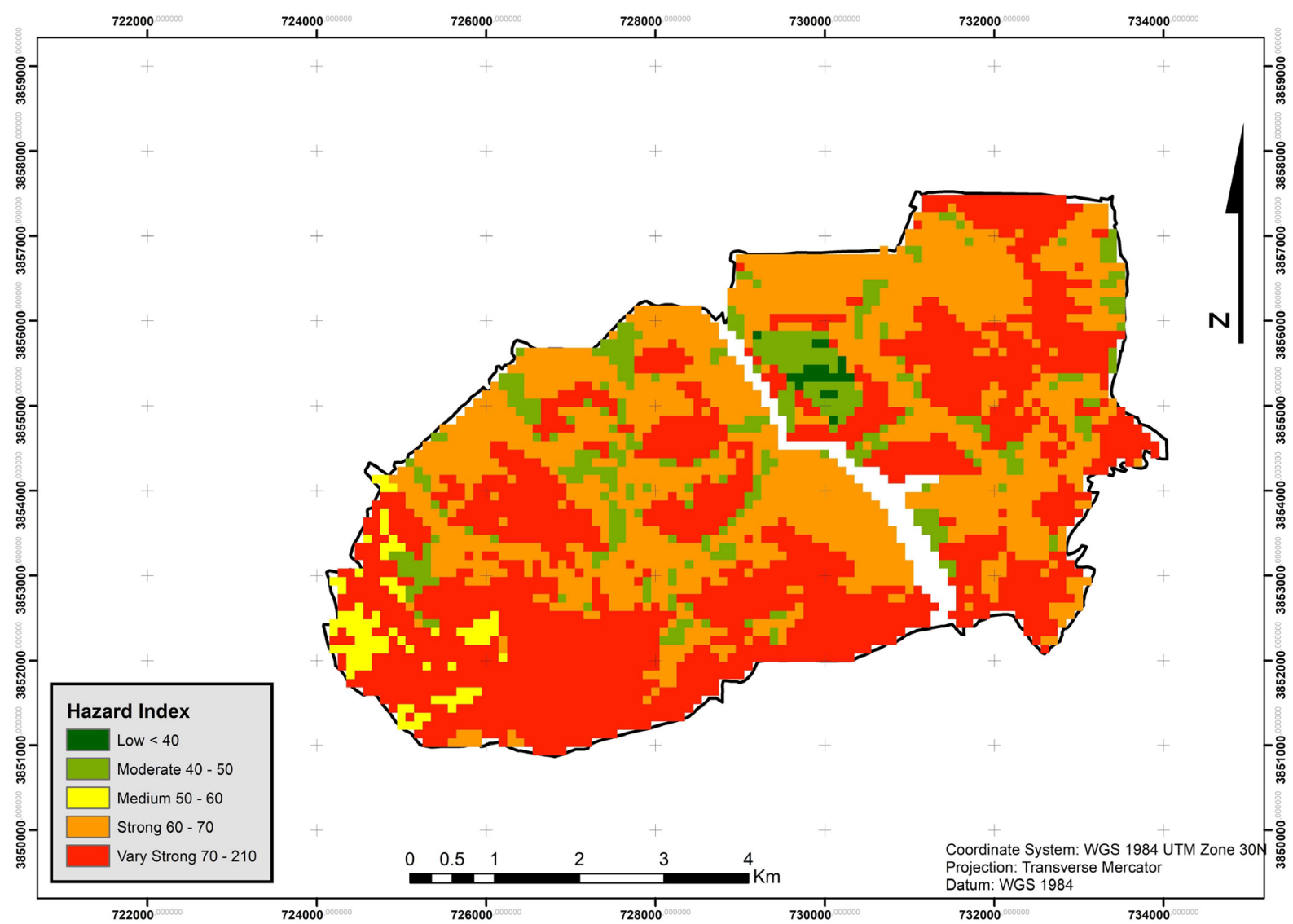

Figure 10. Map of the dangers of the Khoudida forest.

The choice of these stations is imposed by the typology of vegetation which determines four types, namely:

- Station 1: occupied by reforestation of Aleppo pine following a forest fire.

- Station 2: represents a stand of Aleppo pines decimated by forest fires, and naturally replaced by holm oak and putty with a slope of less than $15 \%$.

- Station 3: representing a holm oak and a tree with chest putty.

- Station 4: occupied by a sagebrush steppe with a combustibility index of around 1 on flat ground with very low biomass. This fact considerably reduces the sensitivity to forest fires.

The fire risk assessment at the 4 stations makes it possible to target the vulnerability factors and to produce a matrix which can serve as a reference for similar forest formations. Fire risk prevention completes the mapping and makes it possible to target the vulnerabilities that constitute the sources of risk of forest fires. To do this, risk management is based on a certain number of tools, the so-called "risk center" method is interesting to apply to the forest ecosystem [17] [18].

The approach of "check-lists" is classic but it makes it possible to target the risks by thus identifying the vulnerabilities. The use of topo-morphological, combustibility and risk maps makes it possible to target vulnerabilities according to their severity, which can be assessed at three levels: low, medium and high. 
The thresholds are to be defined for each ecosystem according to its composition, structure and risk [18].

The use of maps, reports and statistics of the fires that this forest has known allows us to target the main dangers, source of fires. For each type of forest formation, the hazards were targeted and assessed on a three-level scale and the results are summarized in Table 3.

Table 3. Fire risk and risk prevention matrix.

\begin{tabular}{ccccccc}
\hline $\begin{array}{c}\text { Source of } \\
\text { Risk }\end{array}$ & Impacts & $\begin{array}{c}\text { Reforestation } \\
\text { after Fire }\end{array}$ & $\begin{array}{c}\text { Aleppo Pine } \\
\text { Forest and } \\
\text { Holm Oak }\end{array}$ & $\begin{array}{c}\text { Matorral of } \\
\text { Holm Oak } \\
\text { and Lentisk }\end{array}$ & $\begin{array}{c}\text { Sagebrush } \\
\text { Steppe }\end{array}$ & Total \\
\hline \multirow{4}{*}{ Management } & 3 & 3 & 3 & 1 & $10 / 12$ \\
& Clearing & 2 & 1 & 3 & 3 & $9 / 12$ \\
\multirow{2}{*}{ works } & Grazing & 3 & 2 & 3 & 3 & $11 / 12$ \\
& Wood exploitation & 0 & 2 & 1 & 0 & $3 / 12$ \\
& Honey exploitation & 1 & 3 & 1 & 0 & $5 / 12$ \\
& Picking plants & 2 & 1 & 2 & 3 & $8 / 12$ \\
Total & & 11 & 12 & 13 & 10 & - \\
\hline
\end{tabular}

The use of this analysis matrix of fire sources and their impact on forest formations allows the following observations:

- the causes of the fires are mainly due to grazing and the lack of development of forest formations.

- land clearing and picking plants occupying the third and fourth positioned.

- in last position the exploitation of wood and the harvest of honey.

The types of forest formations most exposed to fire risks are in descending order: Matorral, forest, reforestation and steppe.

Pressure management should be another priority to prohibit unregulated access to the course during the summer (more than $96 \%$ of fires are concentrated during this period). The clearing induced by the right of use granted within the framework of a law of development of the ground must be completely prohibited because it constitutes the greatest danger with regard to arson.

\section{Conclusions}

The conventional methods usually used in Algeria for fire prevention and fire fighting take time and are not always reliable given the complexity and diversity of forest ecosystems. Work in this area, based on modern techniques of observation and analysis of space (remote sensing and geographic information system), has shown their efficiency and speed in the development of risk assessment maps, of fires in forest areas through thematic analysis of the causes of fires. The results obtained for the Khoudida forest thanks to the development of two maps, that of the dangers and the potential fire risk, justify the use of this method allowing the rapid and acceptable definition of prevention and protection meas- 
ures, and backup required.

The uncertainty, complexity and diversity of factors that control the risk of forest fires mean that prevention by traditional means remains insufficient. The main objective sought was achieved because it is possible thanks to the results obtained, namely the mapping of dangers, that of potential risk and the matrix of identification of fire sources, to act on prevention. The latter is the only effective way to combat this phenomenon. It can only materialize through the contribution of interactive mapping with modern and rapid means such as GIS and remote sensing.

For this we had recourse to the application of a model which involves six parameters: namely the type of vegetation, the slope, the exposure, the altitude, the proximity of the roads and the proximity of the dwellings. The risk map informs us that $89 \%$ of the forest has a high to very high risk. The low and medium risk classes occupy $1 \%$ and $2 \%$ respectively. The high-risk class occupies $41 \%$ and is distributed throughout the forest. The very high risk occupies $48 \%$ and is mainly found in the southwest and the center and east of the forest.

The forest fire risk map itself also makes it possible to improve the forest fire management plan by contributing to the establishment of an adapted intervention system and the acquisition of adequate equipment allowing a more effective intervention.

The validation of the potential fire risk materialized thanks to remote sensing by comparing the NDVI indices of satellite images followed by a geomatics application which will allow:

- Help with decision-making for a reasoned policy in terms of environmental management, in particular in the fight and prevention of forest fires.

- An effective tool for defining priorities for the establishment or maintenance of fire-fighting infrastructure and the development of land exposed to fire risks.

The 3 maps (topo-morphological, combustion index and dangers) made it possible to map the potential risk of fire which makes it possible to undertake development work and equipment such as water points, control points and observation, construction of reservoirs on the hillside, opening of forest tracks and forest management.

\section{Conflicts of Interest}

The authors declare no conflicts of interest regarding the publication of this paper.

\section{References}

[1] FAO (2007) Fire Management Global Assessment 2006. A Thematic Study Prepared in the Framework of the Global Forest Resources Assessment 2005. FAO Forestry Paper No. 151, Rome.

[2] Lavieille, J.M. (2004) Droit international de l'environnement. 2e édition mise à jour, Paris, Ellipses, 191 p. 
[3] Hessas, N. (2007) Evaluation cartographique et évolution diachronique par télédétection du risque incendie de forêt. Simulation de la propagation du feu dans le bassin versant du Paillon, Nice, Alpes Maritimes. Géographie. Université Joseph-Fourier-Grenoble I, 2005. Français. <tel-00142644.

[4] DGF (2007) Superficies, potentialités et bilan d'incendies des forêts algériennes. Rapport, 104 p.

[5] Talbi, O., Benabdeli, K., Benhanifia, K. and Haddouche, D. (2017) Cartographie des zones de risque de feux de forêt dans la commune de Doui Thabet, Saïda, Algérie. International Journal of Environmental Studies, 75, 543-552. https://doi.org/10.1080/00207233.2017.1386434

[6] Haddouche, D., Benhanifia, K. and Gacemi, M. (2011) Spatial Analysis of Forest Regeneration after Fire in the Forest of Fergoug in Mascara, Algeria. Bois et forêts des tropiques, 307, 23-31. https://doi.org/10.19182/bft2011.307.a20478

[7] Missoumi, A. and Tadjouni, K. (2003) SIG et imagerie Alsat1 pour la cartographie du risque d'incendie de forêt en Algérie. 2nd FIG régional conférence, Marrakch, 2-5 Décembre 2003, 14 p.

[8] Belgherbi, B. (2002) Intégration des données de télédétection et des données multi-sources dans un système d'information géographique (SIG) pour la protection des forêts contre les incendies (cas de la forêt de Guetaria-Ouest de l'Algérie). Mémoire Magister, Université de Télemcen, Algérie, 217 p.

[9] Khader, M., Benabdeli, K. and Mederbal, K. (2009) Etude du risque d'incendie à l'aide de la géomantique: Cas de la forêt de Nesmoth (Algérie). Rev. Méditérranea, T. II, No. 20, 39 p. https://doi.org/10.14198/MDTRRA2009.20.07

[10] Benabdeli, K. (1996) Aspects physionomicaux et structure de la vegetation forestière dans les monts de Tlemcen et de Dhaya face à la pression anthropozoogène. Thèse de doctorat d'Etat, université de Sidi Bel Abbes, Algérie, 237 pages + annexes.

[11] Bureau national d'Etudes Forestières (2008) Inventaire forestier des forêts de la région de Tléagh. Algérie, Rapport Final, 187 p.

[12] Xu, D., Dai, L.M. and Shao, G.F. (2005) Forest Fire Risk Zone Mapping from Satellite Images and GIS for Baihe Forestry Bureau, Jilin, China. Journal of Forestry Research, 16, 169-174. https://doi.org/10.1007/BF02856809

[13] Didon, E. (1990) Système d'information géographique: Concepts, fonctions, applications. Laboratoire commun de télédétection CEMAGREF/ENGREF, Montpellier, $44 \mathrm{p}$.

[14] Mariel, A. (1995) Cartographie du niveau de risque d'incendie: Exemple du massif des Maures, CEMAGREF.

[15] Erten, E., Kurgun, V. and Musaoglu, N. (2004) Forest Fire Risk Zone Mapping from Satellite Imagery and GIS Case Study. 20 th ISPRS Congress, Youth Forum, Istanbul, 12-23 July 2004, 33-39.

[16] Dagorne, Y., et al. (1994) Protection des forêts contre les incendies \& Système d'information géographique: Application à la commune d'Auribeau sur Siagne (Alpes Maritimes). Revue Forêt Méditerranéenne, 15, 409-420.

[17] Fetati, R. (2008) Use of Spatial Analysis Tool (Remote Sensing, GIS) for Forest Fire Risk Assessment in Western Algeria, Saïda, Algeria. Maîtrise de Biologie des Populations et des écosystèmes, Université Angers.

[18] Benabdeli, K. and Moulay, A. (2013) Quelle stratégie de gestion durable des territoires forestiers en Algérie face à leur vulnérabilité. IIIème Semaine Forestière Méditerranéenne, Tlemcen, 17-21 March 2013. 